\title{
Soil management for Alfisols in the semiarid tropics: erosion, enrichment ratios and runoff
}

\author{
A.L. Cogle ${ }^{2 *}$, K.P.C. Rao ${ }^{1}$, D.F. Yule ${ }^{2}$, G.D Smith $^{2}$, P.J. George ${ }^{1}$, \\ S.T. Srinivasan ${ }^{1} \&$ L. Jangawad ${ }^{1}$
}

\begin{abstract}
Continuous cultivation of soils of the semiarid tropics has led to significant land degradation. Soil erosion and nutrient loss caused by high runoff volumes have reduced crop yields and contributed to offsite damage. We compared a number of soil management practices (tillage, mulch and perennial/annual rotational based systems) for their potential to improve crop production and land resource protection in an Alfisol of the semiarid tropics of India. Runoff and soil erosion were monitored and surface soil and sediment were analysed for nitrogen and carbon to determine enrichment ratios. Amelioration of soils with organic additions (farmyard manure, rice straw) or rotating perennial pasture with annual crops increased soil carbon and nitrogen contents and reduced runoff, soil erosion and nutrient loss. Soil erosion totalled less than $7 \mathrm{tha}^{-1}$, but enrichment ratios were often greater than 2 resulting in up to $27 \mathrm{~kg} \mathrm{Nha}^{-1}$ and $178 \mathrm{~kg} \mathrm{Cha}^{-1}$ being lost in sediment. Up to an extra $250 \mathrm{~mm}$ of water per year infiltrated the soil with organic additions and was available for crop water use or percolation to groundwater. The results show that there are good opportunities for reducing degradation and increasing productivity on farms.
\end{abstract}

Keywords: Erosion, runoff, nutrient loss, soil management, Alfisols, semiarid zones, tropics, India

\section{INTRODUCTION}

$\mathrm{L}$ and degradation affects 166 million ha in the semiarid tropics (SAT) of India, with soil erosion by water being the single most important mechanism (Sehgal \& Abrol 1992). A large proportion (33\%) of the soils in the SAT are Alfisols (Kampen \& Burford 1980), and they are important for agricultural production for large numbers of people worldwide. Alfisols are subject to low productivity and soil degradation (El-Swaify et al. 1985), and have several characteristics, which make management difficult. These include low water holding capacity, poor surface soil stability and high soil strength when dry. Continuous cultivation, based on multiple tillage operations over many years, has reduced organic matter levels and exacerbated these problems causing increased runoff and erosion.

Soil erosion is dependent on the flow of overland water (or runoff) and its sediment concentration (Hairsine et al. 1992). Reducing soil erosion requires lower runoff volumes and less opportunity for the soil to become entrained. Another concern is that since the fine fraction, containing nutrients, is often preferentially eroded, a disproportionate loss of the soil nutrients can occur, leading to even greater

${ }^{1}$ ICRISAT, PO Patancheru, 502324, AP, India. ${ }^{2}$ Present Address: Department of Natural Resources and Mines, Peters St, Mareeba. 4880 Queensland, Australia.

*Corresponding author: Fax: 0061-7-40923593. E-mail: lex.cogle@dnr.qld. gov.au degradation (Hashim et al. 1998). Enrichment ratios are the common descriptor of such a process and are defined as the ratio of nutrient concentration in eroded sediment to that in the original soil (Pallis et al. 1990).

Soil management practices, need to be identified and implemented that reduce runoff, erosion and nutrient loss, but which also increase productivity. A range of potential systems exists and can be categorized as tillage and biologically based systems. Tillage increases infiltration by increasing porosity, destroying surface crusts and manipulating surface roughness. However, tillage can also degrade soils. Biologically based options include mulch and pasture systems to increase infiltration (Rao et al. 1992). Mulches are used to protect the soil surface from raindrop impact and subsequent crust formation and to reduce the rate of organic matter decline. In addition to mulching benefits, a pasture phase also creates root channels and increases organic matter throughout the profile (Smith et al. 1988). A legume pasture may contribute soil nitrogen. Smith et al. (1992) outlined an experiment to compare a range of tillage and biological systems; improvements in productivity via additions of farmyard manure and plant residues, or pasture/crop rotations were reported (Cogle et al. 1997). The impact of these soil management choices on erosion, nitrogen and carbon losses and runoff is discussed in this paper, and recommendations for improving the sustainability of SAT farms are made. 


\section{MATERIALS AND METHODS}

\section{Experimental site}

The project was established in July 1988 at the International Crops Research Institute for the Semi Arid Tropics (ICRISAT), Patancheru $\left(18^{\circ} \mathrm{N}, 78^{\circ} \mathrm{E}\right), 26 \mathrm{~km}$ north west of Hyderabad, Andhra Pradesh, India. Details of the experimental site and the 1988 crop season were given by Smith et al. (1992).

The soil belongs to the Patancheru series, a member of the family of Udic Rhodustalfs (Murthy \& Swindale 1993), locally regarded as a crusting, hardsetting soil. The surface texture is a sandy loam merging to a sandy clay loam or light clay at $10-15 \mathrm{~cm}$ and then to gravelly sandy loam overlying murrum (a layer of decomposing parent material); the depth of the murrum varies between 30 to $100 \mathrm{~cm}$. ICRISAT has an average rainfall of $784 \mathrm{~mm}$, with over $80 \%$ falling between the months of June and October. Average monthly air temperature in the rainy season range from 25 to $29^{\circ} \mathrm{C}$.

\section{Experimental design}

The experimental design was an incomplete randomized block with an embedded factorial for the tillage by amendment comparisons. Each plot was $28 \mathrm{~m}$ long (down slope) and $5 \mathrm{~m}$ wide with a land slope between $1.5-2.0 \%$. There were three replications. Fifteen treatments were imposed in the experiment. These were made up of:

(1) A tillage by amendment factorial for annual crops, comprised nine treatments and compared three different tillage depths at $0 \mathrm{~cm}\left(\mathrm{~T}_{0}\right), 10 \mathrm{~cm}\left(\mathrm{~T}_{10}\right)$ and $20 \mathrm{~cm}\left(\mathrm{~T}_{20}\right)$ and three mulches, no mulch $\left(\mathrm{N}_{\mathrm{m}}\right), 15 \mathrm{tha}^{-1}$ farmyardmanure $\left(F_{m}\right)$, and $5 \mathrm{tha}^{-1}$ rice straw $\left(\mathrm{R}_{\mathrm{m}}\right)$, which were applied annually.

(2) Perennial species, which were rotated to annual crops after four years comprised six treatments : sole perennial pigeon pea (P) (Cajanus cajan $\mathrm{L}$ ), sole buffel grass (C) (Cenchrus ciliaris L)., sole Verano (St) (Stylosanthes hamata L.), and mixtures of these species i.e.. PSt (perennial pigeon pea and Stylosanthes hamata), PCSt (perennial pigeon pea, Cenchrus ciliaris and Stylosanthes hamata) and CSt (Cenchrus ciliaris and Stylosanthes hamata). The perennial species were harvested each year. Agronomic details and harvest information are provided by Cogle et al. (1997).

Between 1988 and 1991 the tillage and mulch treatments were cropped annually to cereal crops. In 1992, perennial crops were removed and in 1992 and 1993 all treatments including those previously under perennial crops were planted to a cereal crop to compare the cumulative effects of different soil management histories. For discussion of the 1992 and 1993 results, the perennial treatments are referred to as 'prior-perennial' treatments when compared with the treatments that have been cropped to annual crops before 1992 , but retain the same abbreviation.

Data were analysed using GENSTAT (GENSTAT 5 Committee, 1993) with data adjusted to take account of the incomplete block design, prior to analysis. Adjusted means are presented.

Annual crops (tillage by amendment) factorial

The crop sequence was millet (Pennisetum glaucum L.) (1988), sorghum (Sorghum bicolor L.) (CSH9), (1989, 1990), maize (Zea mays L.) (Proagro 3448), (1991, 1992) and sorghum (CSH9), (1993). Smith et al. (1992) discussed the millet crop, while Cogle et al. (1997) discussed crops between 1989 and 1993 .

Tillage for $\mathrm{T}_{10}$ and $\mathrm{T}_{20}$ treatments occurred after the first major rain in June and was performed with a tractormounted toolbar using chisel tines. The initial tillage operation was to $10 \mathrm{~cm}$ in both treatments, while a second tillage to $10 \mathrm{~cm}$ and $20 \mathrm{~cm}$ was performed for $T_{10}$ and $T_{20}$ treatments respectively. There were a total of two passes in tilled plots. In each year, planting was performed as soon as possible after tillage, but in 1989 and 1990 a delay of several weeks occurred because of unfavorable weather conditions. Seeds were sown by hand in a furrow at double the desired plant population and furrows were firmed to promote soilseed contact. Approximately 20 days after planting, seedlings were thinned to give the desired population.

Fertilizer was placed in the seed furrow and mixed with soil prior to planting. Nitrogen $(\mathrm{N})$ applications were made 2-3 times during the crop season. Fertilizer (diammonium phosphate and urea) at a rate of $100 \mathrm{~kg} \mathrm{Nha}^{-1}$ and $46 \mathrm{~kg} \mathrm{P} \mathrm{ha}^{-1}$ was applied over most of the plot and designated as the normal fertilizer level.

After planting, farmyard-manure $\left(15 \mathrm{tha}^{-1}\right)$ was applied to $F_{m}$ plots and rice straw $\left(5 \mathrm{tha}^{-1}\right)$ was applied to $R_{m}$ plots. Both mulches were applied to the surface and not incorporated. In 1992 and 1993, rice straw was applied to all prior-perennial plots, except PCSt. The rationale for straw application to prior perennials was to prevent the development of a surface seal/crust and therefore allow a comparison of the effect of subsurface structural changes. The PCSt treatment did not receive straw so as to be able to measure the effect of a pasture/crop rotation in a nonmulched situation. The farmyard manure used contained $157 \mathrm{~kg} \mathrm{Nha}^{-1}, 81 \mathrm{kgPha}^{-1}$ and $127 \mathrm{~kg} \mathrm{Kha}^{-1}$, and the rice straw contained $35 \mathrm{~kg} \mathrm{Nha}^{-1}, 7 \mathrm{~kg} \mathrm{Pha}^{-1}$ and $86 \mathrm{~kg} \mathrm{~K} \mathrm{ha}^{-1}$

Agronomic management and data collection has previously been presented Cogle et al. (1997).

\section{Rainfall and runoff measurement}

Rainfall rate was measured at one minute intervals in a tipping bucket pluviometer $\left(0.2 \mathrm{~mm} \mathrm{tip}^{-1}\right)$ and recorded on a data logger. Runoff from each plot was channeled through a sediment settling trough $(25 \mathrm{~cm}$ deep by $22 \mathrm{~cm}$ wide), and the flow rate measured by a calibrated tipping bucket (approx. $0.05 \mathrm{~mm}$ of runoff $\mathrm{tip}^{-1}$ ) and recorded on the same data logger at one minute intervals. Smith \& Thomas (1988) provide further details.

\section{Annual, preplanting and crop periods}

To assist data interpretation, the results are presented in three forms. Annual results are the annual total. Preplanting period represents the combined data prior to tillage and sowing. Crop period represents combined data between sowing and harvest.

\section{Bedload and suspended load measurement}

Runoff bedload was collected in the trough at the end of each runoff event, dried, weighed and in later years, subsampled for chemical analysis. In 1992, a flow splitting 
Table 1. Annual runoff (mm) and annual bedload $\left(\mathrm{kg} \mathrm{ha}^{-1}\right)$ between 1989 and 1993 for 15 soil management treatments.

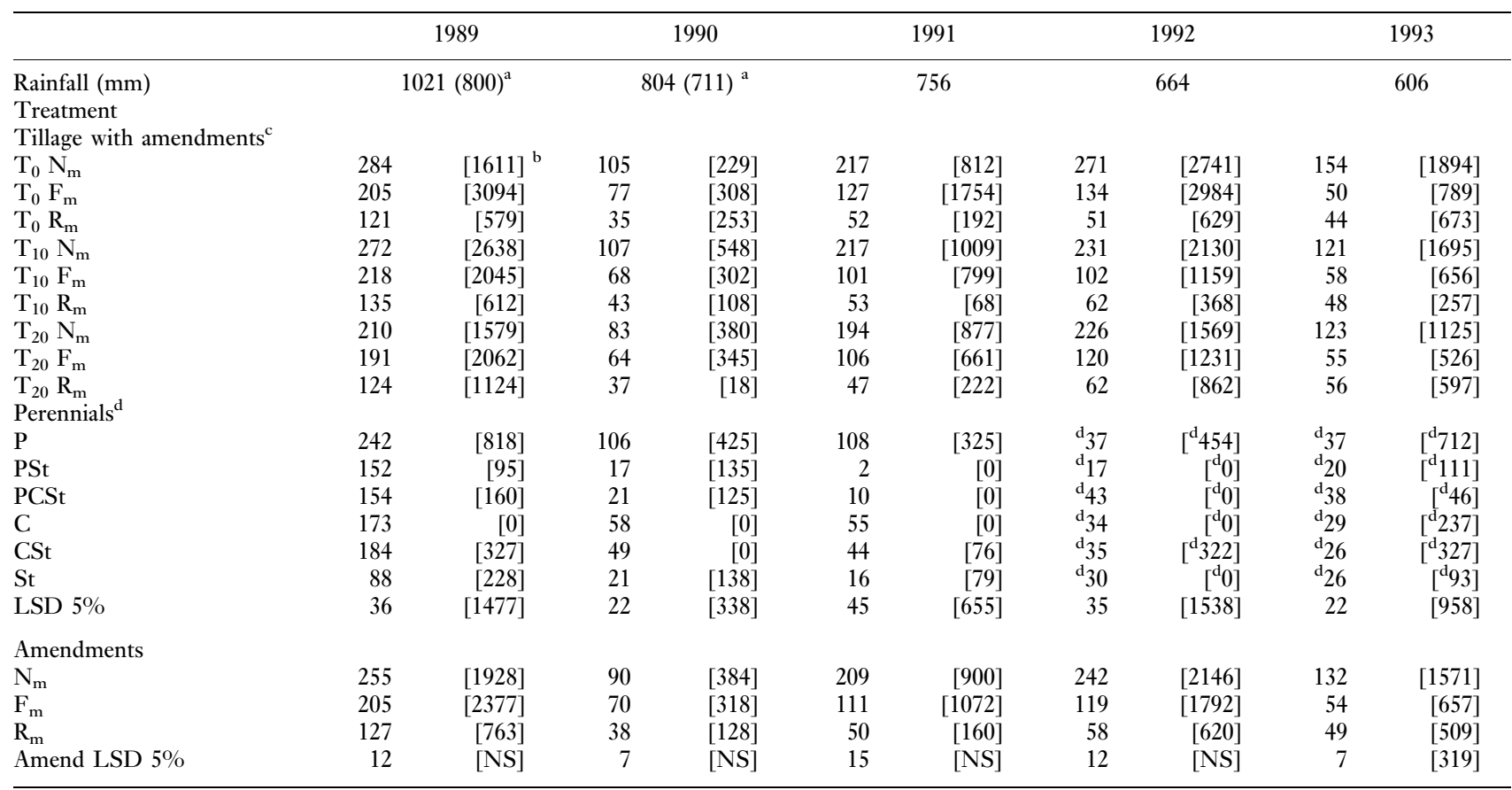

${ }^{\mathrm{a}}$ Figures in brackets represent rainfall for which runoff was measured in 1989 and $1990 .{ }^{\mathrm{b}}$ Figures in [ ] brackets are the annual bedload (kg ha ${ }^{-1}$ ) ${ }^{\mathrm{c}} \mathrm{T}_{0} 0 \mathrm{~cm}$ tillage depth; $\mathrm{T}_{10}-10 \mathrm{~cm}$ tillage depth; $\mathrm{T}_{20}-20 \mathrm{~cm}$ tillage depth. $\mathrm{N}_{\mathrm{m}}-\mathrm{no}$ mulch; $\mathrm{F}_{\mathrm{m}}-15 \mathrm{tha}^{-1}$ farmyard manure; $\mathrm{R}_{\mathrm{m}}-5 \mathrm{tha}^{-1}$ rice straw. ${ }^{\mathrm{d}} \mathrm{In}$ 1992, 1993 these plots had the perennial crop removed and an annual grain crop was planted. $\mathrm{P}$-sole perennial pigeon pea; $\mathrm{C}-$ sole Cenchrus ciliaris; St-sole Stylosanthes hamata; PSt - perennial pigeon pea and Stylosanthes hamata; PCSt-perennial pigeon pea, Cenchrus ciliaris and Stylosanthes hamata; CSt-Cenchrus ciliaris and Stylosanthes hamata.

device was installed to subsample runoff from the tipping buckets. Samples from the flow splitter were collected and dried for determination of sediment concentration in runoff water. The suspended sediment was also retained for nutrient analysis.

\section{Soil sampling and chemical analysis}

Eight randomly identified locations were identified within each runoff plot. Soils were sampled to $0-1.5 \mathrm{~cm}$ and 0 $10 \mathrm{~cm}$ and bulked for the plot after harvest in 1992 . Nitrogen determinations were made using the Kjeldhal method and organic carbon using chromic acid digestion with no external heating.

\section{Enrichment ratios}

The enrichment ratios (ER) for carbon and nitrogen were calculated using the following formula (Hashim et al. 1998).

$$
\begin{aligned}
\mathrm{ER}= & \text { Nutrient concentration in sediment / } \\
& \text { Nutrient concentration in topsoil }
\end{aligned}
$$

The calculation was done using topsoil depths of $0-1.5 \mathrm{~cm}$ and $0-10 \mathrm{~cm}$. These depths were chosen as it was thought that smaller depth increments might more adequately represent the eroded soil depth.

\section{RESULTS}

Runoff

Annual runoff, as a percentage of rainfall, ranged from 0 to $41 \%$. The most runoff was always from the unamended and

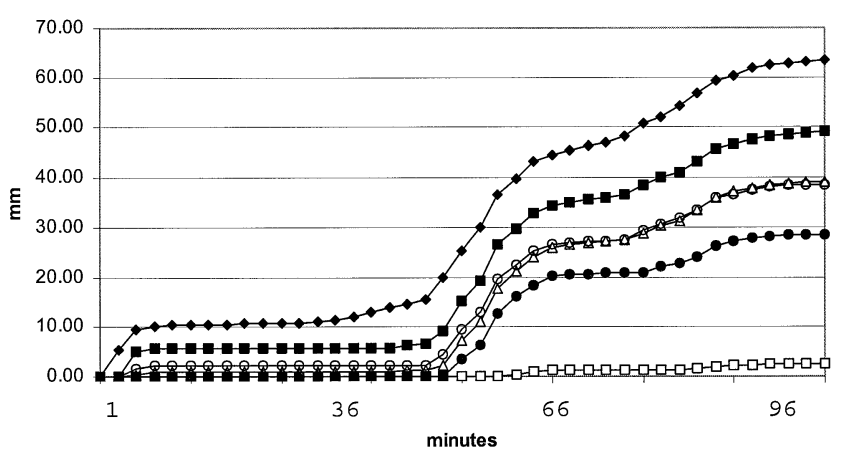

Figure 1. Runoff event on 2 July 1992 showing hydrograph for several treatments. (PSt is not shown on the figure but yielded no runoff during the period.). (Rain-,$- \mathrm{T}_{0} \mathrm{~N}_{\mathrm{m}}-\mathbf{\square} ; \mathrm{T}_{0} \mathrm{~F}_{\mathrm{m}}-\triangle ; \mathrm{T}_{0} \mathrm{R}_{\mathrm{m}}-\square, \mathrm{T}_{20} \mathrm{~N}_{\mathrm{m}}-\bigcirc$; PCST-๑). See Table 1 for treatment key.

untilled soils $\left(\mathrm{T}_{0} \mathrm{~N}_{\mathrm{m}}\right)$, while the least was always one of the perennial treatments.

Organic amendments, of farmyard manure $\left(\mathrm{F}_{\mathrm{m}}\right)$ and straw $\left(\mathrm{R}_{\mathrm{m}}\right)$, significantly reduced $(P<0.05)$ annual runoff, compared to unamended treatments $\left(\mathrm{N}_{\mathrm{m}}\right)$, in all years (Table 1). The perennials generally had a similar impact, except for sole pigeon pea (P) in 1990. After 1992, when annual crops with or without straw replaced perennials, runoff from these treatments was also significantly reduced $(P<0.05)$. The perennials produced less runoff than farmyard manure amended soils, except for sole pigeon pea in 1989 and 1990.

Tillage had little effect on runoff between 1989 and 1991, but in 1992 and 1993 tillage reduced $(P<0.05)$ runoff 


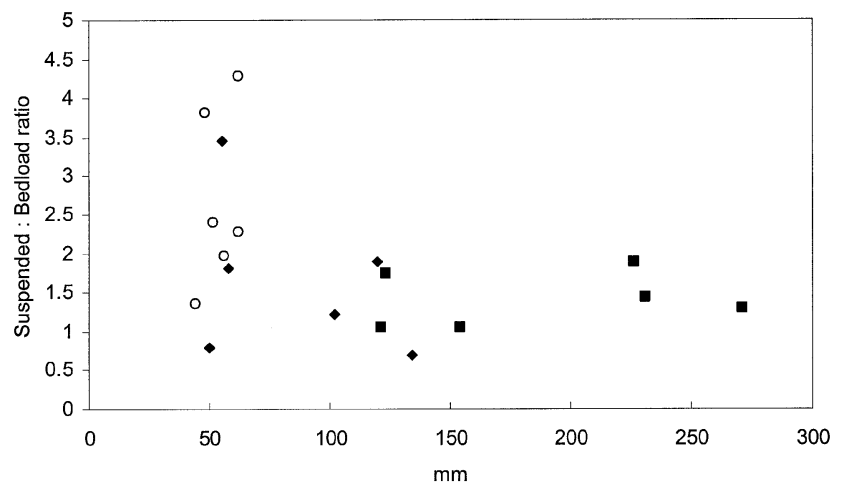

Figure 2. The ratio between suspended load and bedload for runoff events in 1992 and 1993. $\left(\mathrm{N}_{\mathrm{m}}-\mathbf{-} ; \mathrm{R}_{\mathrm{m}}-\mathrm{O} ; \mathrm{F}_{\mathrm{m}}-\boldsymbol{)}\right)$. See Table 1 for treatment key.

compared to zero tillage under unamended $\left(\begin{array}{lll}T_{0} & N_{m}\end{array}\right)$, conditions (Table 1).

During the period prior to tillage and planting, runoff was least from treatments, which had either, a perennial or had been rotated out of perennials for cropping (data not shown). The exception was 1989 , when perennial pastures were establishing and cover was low. Treatments which had straw applied in the previous cropping cycle produced the least runoff from the tillage by amendment treatments. In 1991, 1992 and 1993, runoff was similar for farmyard manure $\left(\mathrm{F}_{\mathrm{m}}\right)$ and straw amended $\left(\mathrm{R}_{\mathrm{m}}\right)$ soils during this pre tillage/planting period. In all years the unamended treatments $\left(\mathrm{N}_{\mathrm{m}}\right)$ produced the greatest runoff.

An event recorded on 2 July 1992 was unusual during the project cycle. It occurred after soil management treatments had been imposed, but before crops had emerged. The runoff hydrograph (Figure 1) clearly illustrated the impact of: (a) tillage [runoff from tilled treatments $\left(\begin{array}{ll}\mathrm{T}_{20} & \mathrm{~N}_{\mathrm{m}}\end{array}\right)$ was less than untilled $\left(\mathrm{T}_{0} \mathrm{~N}_{\mathrm{m}}\right)$ ]; (b) cover [straw cover $\left(T_{0} R_{m}\right)$ significantly reduced runoff]; (c) organic addition [farmyard manure $\left(\mathrm{T}_{0} \mathrm{~F}_{\mathrm{m}}\right)$ reduced runoff]; and (d) perennial rotations, which had not received additional surface straw cover [PCSt reduced runoff compared to $\mathrm{T}_{0} \mathrm{~N}_{\mathrm{m}}$ ].

Crops were planted between mid June and mid July depending on the incidence of planting rain (Cogle et al. 1997). The runoff response (data not shown) during this period represents both the soil management and the development of a crop canopy. Runoff was significantly reduced $(P<0.05)$ by both organic amendment and tillage in all years. The reduction was greatest for straw amended soils but in 1993, runoff was similar for both farmyard manure and straw amended soils. The reduction in runoff caused by tillage declined with increasing rainfall during each season, to the extent that shallow tilled plots $\left(\mathrm{T}_{10}\right)$ showed little or no benefit from tillage after $200 \mathrm{~mm}$ of rainfall and deep tilled plots $\left(\mathrm{T}_{20}\right)$ after $400 \mathrm{~mm}$ of rainfall (Littleboy et al. 1996a; Rao et al. 1998a).

Runoff from treatments rotated out of perennials for cropping in 1992 and 1993, was generally similar to that from straw amended $\left(R_{m}\right)$ tillage by amendment treatments in these years.
Table 2. Annual soil erosion (bedload + suspended load) $\left(\mathrm{kg} \mathrm{ha}^{-1}\right)$ between 1992 and 1993 for 15 soil management treatments.

\begin{tabular}{lrr}
\hline & 1992 & 1993 \\
\hline Rainfall $(\mathrm{mm})$ & 664 & 606 \\
Treatment & & \\
Tillage with amendments & 6300 & 3907 \\
$\mathrm{~T}_{0} \mathrm{~N}_{\mathrm{m}}$ & 5052 & 1421 \\
$\mathrm{~T}_{0} \mathrm{~F}_{\mathrm{m}}$ & 2135 & 1590 \\
$\mathrm{~T}_{0} \mathrm{R}_{\mathrm{m}}$ & 5210 & 3470 \\
$\mathrm{~T}_{10} \mathrm{~N}_{\mathrm{m}}$ & 2574 & 1848 \\
$\mathrm{~T}_{10} \mathrm{~F}_{\mathrm{m}}$ & 1947 & 1238 \\
$\mathrm{~T}_{10} \mathrm{R}_{\mathrm{m}}$ & 4550 & 3088 \\
$\mathrm{~T}_{20} \mathrm{~N}_{\mathrm{m}}$ & 3561 & 2343 \\
$\mathrm{~T}_{20} \mathrm{~F}_{\mathrm{m}}$ & 2819 & 1778 \\
$\mathrm{~T}_{20} \mathrm{R}_{\mathrm{m}}$ & & \\
Perennials & 1092 & 1597 \\
$\mathrm{P}$ & 6 & 501 \\
PSt & 286 & 408 \\
PCSt & 570 & 910 \\
$\mathrm{C}$ & 638 & 837 \\
$\mathrm{CSt}$ & 466 & 494 \\
$\mathrm{St}$ & 2539 & 1452 \\
LSD 5\% & & \\
Amendments & 5353 & 3488 \\
$\mathrm{~N}_{\mathrm{m}}$ & 3730 & 1871 \\
$\mathrm{~F}_{\mathrm{m}}$ & 2301 & 1535 \\
$\mathrm{R}_{\mathrm{m}}$ & 334 & 319 \\
Amend LSD 5\% & & \\
\hline Ab & & \\
\hline
\end{tabular}

Abbreviations as Table 1

\section{Erosion}

Annual soil loss, as bedload, was always lowest in straw amended treatments (Table 1). In 1993, this trend was significant with unamended treatments $\left(\mathrm{N}_{\mathrm{m}}\right)$ yielding greater $(P<0.05)$ bedload, than farmyard manure $\left(\mathrm{F}_{\mathrm{m}}\right)$ and straw amended $\left(R_{m}\right)$ treatments. In 1989 and 1990, bedload was higher from $\mathrm{F}_{\mathrm{m}}$ treatments than from $\mathrm{N}_{\mathrm{m}}$, particularly in $\mathrm{T}_{0}$ treatments, however this response did not occur in 1992 and 1993. The annual bedload ranged between 18 and $3094 \mathrm{~kg} \mathrm{ha}^{-1}$ for the tillage by amendment treatments but only between 0 and $818 \mathrm{~kg} \mathrm{ha}^{-1}$ for perennial (1989-91) and cropped prior perennial treatments (1992-3).

In 1992 and 1993, suspended load measurements were confidently made. Figure 2 shows that these contribute at least half of total soil loss, and for lower runoff volumes, the suspended load component dominates the total soil loss. Using these measurements, total soil loss for 1992 and 1993 (Table 2), ranged up to $6300 \mathrm{~kg} \mathrm{ha}^{-1}$ under unamended zero tillage $\left(\mathrm{T}_{0} \mathrm{~N}_{\mathrm{m}}\right)$ conditions. It is notable that soil loss from prior perennials was substantially and sometimes significantly lower than that from the tillage by amendment factorial, even for the PCSt, which was not amended with straw.

During the preplanting period, erosion varied across years. Between 1989 and 1991, bedload was less than $695 \mathrm{~kg} \mathrm{ha}^{-1}$, except in 1989 for $\mathrm{T}_{0} \mathrm{~F}_{\mathrm{m}}$ and $\mathrm{T}_{10} \mathrm{~N}_{\mathrm{m}}$. In 1992 and 1993, the suspended load component was also measured and in most treatments was higher than the measured bedload. Highest combined soil loss (bedload plus suspended load) during the 1992 and 1993 preplanting period was $2436 \mathrm{~kg} \mathrm{ha}^{-1}$ for $\mathrm{T}_{0} \mathrm{~F}_{\mathrm{m}}$ in 1992. Erosion from perennials (1989-1991) and from cropped prior perennials (1992-1993) 
was less than from the tillage by amendment treatments, except from sole pigeon pea $(\mathrm{P})$. Erosion from the $\mathrm{P}$ treatment was always the highest of the perennial or cropped prior perennial treatments (1989-1993).

Erosion during the cropping period (planting-harvest) was dramatically reduced $(P<0.05)$ by straw amendment for all years. Erosion from farmyard manure treatments $\left(F_{m}\right)$ was variable, but generally low. Mobilization of surface amended farmyard manure did occur early in the cropping period in 1989, and in the $\mathrm{T}_{0} \mathrm{~F}_{\mathrm{m}}$ treatment in 1991 .

Table 3. C and N concentrations of topsoil in 1992.

\begin{tabular}{lcccr}
\hline & \multicolumn{2}{c}{$0-1.5 \mathrm{~cm}$} & \multicolumn{2}{c}{$0-10 \mathrm{~cm}$} \\
Treatment & $\mathrm{C}(\%)$ & $\mathrm{N}(\mathrm{ppm})$ & $\mathrm{C}(\%)$ & $\mathrm{N}(\mathrm{ppm})$ \\
\hline Tillage with amendments & & & \\
$\mathrm{T}_{0} \mathrm{~N}_{\mathrm{m}}$ & 0.86 & 1177 & 0.76 & 1075 \\
$\mathrm{~T}_{0} \mathrm{~F}_{\mathrm{m}}$ & 1.29 & 1236 & 0.96 & 1251 \\
$\mathrm{~T}_{0} \mathrm{R}_{\mathrm{m}}$ & 1.09 & 1140 & 0.77 & 1090 \\
$\mathrm{~T}_{10} \mathrm{~N}_{\mathrm{m}}$ & 0.67 & 1206 & 0.64 & 938 \\
$\mathrm{~T}_{10} \mathrm{~F}_{\mathrm{m}}$ & 1.23 & 1432 & 0.98 & 1231 \\
$\mathrm{~T}_{10} \mathrm{R}_{\mathrm{m}}$ & 1.15 & 1341 & 0.87 & 1111 \\
$\mathrm{~T}_{20} \mathrm{~N}_{\mathrm{m}}$ & 0.83 & 1111 & 0.61 & 931 \\
$\mathrm{~T}_{20} \mathrm{~F}_{\mathrm{m}}$ & 1.22 & 1308 & 1.03 & 1330 \\
$\mathrm{~T}_{20} \mathrm{R}_{\mathrm{m}}$ & 1.00 & 1461 & 0.82 & 1111 \\
Perennial & & & & \\
$\mathrm{P}$ & 0.79 & 1223 & 0.82 & 1093 \\
PSt & 1.39 & 1162 & 0.85 & 1147 \\
PCSt & 1.15 & 1186 & 0.77 & 1008 \\
$\mathrm{C}$ & 1.16 & 1276 & 0.99 & 1282 \\
$\mathrm{CSt}$ & 1.21 & 1054 & 0.87 & 1151 \\
St & 1.39 & 1170 & 0.95 & 1241 \\
LSD 5\% & 0.32 & $\mathrm{NS}$ & 0.13 & 134 \\
Amendments & & & & \\
$\mathrm{N}_{\mathrm{m}}$ & 0.79 & 1165 & 0.67 & 981 \\
$\mathrm{~F}_{\mathrm{m}}$ & 1.25 & 1325 & 0.99 & 1271 \\
$\mathrm{R}_{\mathrm{m}}$ & 1.08 & 1314 & 0.82 & 1104 \\
Amend LSD 5\% & 0.11 & $\mathrm{NS}$ & 0.04 & 45 \\
\hline & & & &
\end{tabular}

Abbreviations as Table 1
Soil eroded from all treatments during the 2 July 1992 event except PSt. The greatest loss was from unamended $\left(\mathrm{N}_{\mathrm{m}}\right)$ or farmyard manure $\left(\mathrm{F}_{\mathrm{m}}\right)$ amended treatments with up to $2146 \mathrm{~kg} \mathrm{ha}^{-1}$ and $1827 \mathrm{~kg} \mathrm{ha}^{-1}$ removed respectively. The suspended component was generally the main contributor to the total quantity of soil lost.

\section{Soil nitrogen and carbon in 1992}

Five years of surface amending soils with farmyard manure $\left(\mathrm{F}_{\mathrm{m}}\right)$ or rice straw $\left(\mathrm{R}_{\mathrm{m}}\right)$, increased the soil carbon \% and nitrogen $\left(\mathrm{mg} \mathrm{kg}^{-1}\right)$ compared to soils, which had not been amended, but had undergone similar tillage and fertilization regimes $\left(\mathrm{N}_{\mathrm{m}}\right)$ (Table 3 ). The response was significant $(P<0.05)$ for carbon for most tillage depths and sampling depths, however there were fewer significant differences for nitrogen.

Perennials had been grown for 4 years (1988-1991) and subsequently these plots were cleared and maize grown in 1992. All but PCSt had surface application of straw. In the $0-1.5 \mathrm{~cm}$ depth, there were several significant increases in carbon \%, mostly related to whether St had been a component of the perennial phase.

\section{Loss of nitrogen and carbon in 1992}

Nitrogen removed in bedload during 1992 was least $(P<0.05)$ for straw amended and prior perennial treatments and greatest for the $\mathrm{T}_{0} \mathrm{~F}_{\mathrm{m}}$ treatment. (Table 4). However, there was little difference in the nitrogen removed in suspended load between all tillage by amendment treatments; these being generally significantly higher $(P<0.05)$ than suspended load from prior perennials. Total removal of nitrogen ranged between 12 and $27 \mathrm{~kg} \mathrm{Nha}^{-1}$ for the tillage by amendment treatments and between 1 and $6 \mathrm{~kg} \mathrm{Nha}^{-1}$ for the prior perennial treatments.

Carbon removal followed similar trends to those for nitrogen and included a high bedload content of carbon in

Table 4. Loss $\left(\mathrm{kg} \mathrm{ha}^{-1}\right)$ of $\mathrm{N}$ and $\mathrm{C}$ in bedload and suspended load in 1992.

\begin{tabular}{|c|c|c|c|c|c|c|}
\hline Treatment & Bedload N & Susp N & Total N & Bedload C & Susp C & Total C \\
\hline \multicolumn{7}{|c|}{ Tillage with amendments } \\
\hline $\mathrm{T}_{0} \mathrm{~N}_{\mathrm{m}}$ & 9 & 17 & 26 & 42 & 70 & 112 \\
\hline $\mathrm{T}_{0} \mathrm{~F}_{\mathrm{m}}$ & 15 & 12 & 27 & 127 & 51 & 178 \\
\hline $\mathrm{T}_{0} \mathrm{R}_{\mathrm{m}}$ & 3 & 13 & 16 & 26 & 39 & 65 \\
\hline $\mathrm{T}_{10} \mathrm{~N}_{\mathrm{m}}$ & 6 & 13 & 19 & 44 & 61 & 105 \\
\hline $\mathrm{T}_{10} \mathrm{~F}_{\mathrm{m}}$ & 6 & 7 & 13 & 46 & 35 & 81 \\
\hline $\mathrm{T}_{10} \mathrm{R}_{\mathrm{m}}$ & 2 & 10 & 12 & 15 & 35 & 46 \\
\hline $\mathrm{T}_{20} \mathrm{~N}_{\mathrm{m}}$ & 5 & 11 & 16 & 35 & 39 & 74 \\
\hline $\mathrm{T}_{20} \mathrm{~F}_{\mathrm{m}}$ & 6 & 12 & 18 & 51 & 48 & 99 \\
\hline $\mathrm{T}_{20} \mathrm{R}_{\mathrm{m}}$ & 2 & 10 & 12 & 15 & 35 & 50 \\
\hline $\mathrm{P}$ & 2 & 4 & 6 & 17 & 12 & 29 \\
\hline PSt & 1 & 1 & 2 & 6 & 10 & 16 \\
\hline PCSt & 0 & 1 & 1 & 2 & 7 & 9 \\
\hline $\mathrm{C}$ & 0 & 3 & 3 & 2 & 8 & 10 \\
\hline $\mathrm{CSt}$ & 1 & 3 & 4 & 4 & 3 & 7 \\
\hline St & 1 & 4 & 5 & 10 & 12 & 22 \\
\hline LSD 5\% & 4 & 6 & - & 22 & 22 & - \\
\hline \multicolumn{7}{|l|}{ Amendments } \\
\hline $\mathrm{N}_{\mathrm{m}}$ & 7 & 14 & 21 & 41 & 57 & 98 \\
\hline $\mathrm{F}_{\mathrm{m}}$ & 9 & 10 & 19 & 74 & 45 & 119 \\
\hline $\mathrm{R}_{\mathrm{m}}$ & 2 & 11 & 13 & 19 & 35 & 54 \\
\hline Amend LSD 5\% & NS & NS & - & NS & NS & - \\
\hline
\end{tabular}

Abbreviations as Table 1 


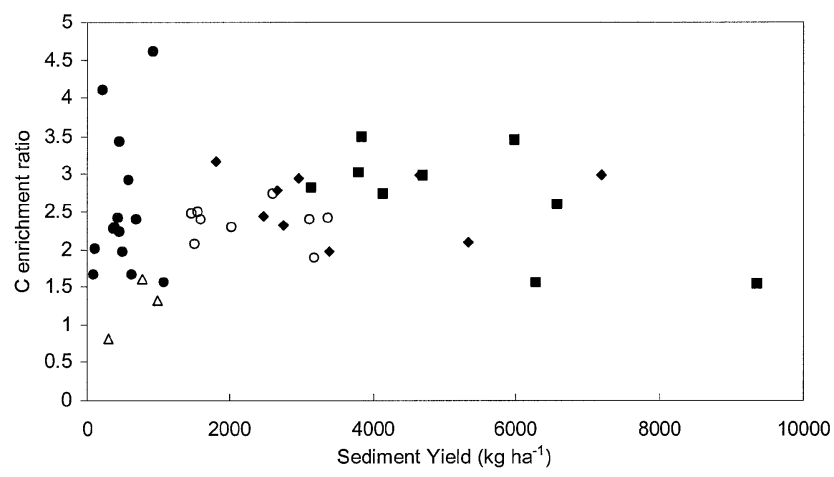

Figure 3. Carbon enrichment ratio in eroded sediment based on surface $1.5 \mathrm{~cm}$. $\left(\mathrm{N}_{\mathrm{m}}-\boldsymbol{\square}\right.$; Perennials plus $\mathrm{R}_{\mathrm{m}}-\mathbf{-}$; $\mathrm{F}_{\mathrm{m}}-\diamond ; \mathrm{R}_{\mathrm{m}}-\mathrm{O}$; Perennials minus $R_{m}-\triangle$ ). See Table 1 for treatment key.

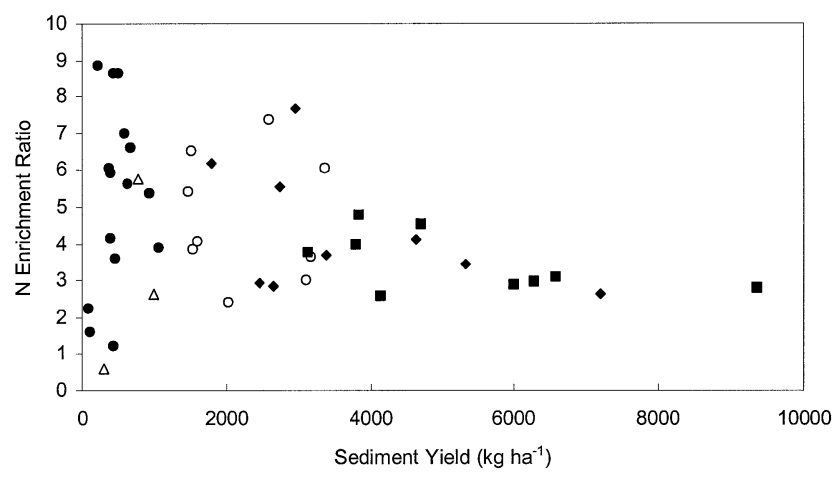

Figure 4. Nitrogen enrichment ratio in eroded sediment based on surface $1.5 \mathrm{~cm}$. $\quad\left(\mathrm{N}_{\mathrm{m}}-\mathbf{\square}\right.$; Perennials plus $\mathrm{R}_{\mathrm{m}}-\mathbf{-} ; \mathrm{F}_{\mathrm{m}}-\diamond ; \mathrm{R}_{\mathrm{m}}-\mathrm{O}$; Perennials minus $R_{m}-\triangle$ ). See Table 1 for treatment key.

the $\mathrm{T}_{0} \mathrm{~F}_{\mathrm{m}}$ treatment (Table 4). Total carbon lost ranged between 50 and $178 \mathrm{~kg} \mathrm{Cha}^{-1}$ for the tillage by amendment treatments and between 7 and $29 \mathrm{kgCha}^{-1}$ for prior perennial treatments.

During the 2 July event there was a large amount of nitrogen (up to $9 \mathrm{~kg} \mathrm{ha}^{-1}$ ) and carbon (up to $57.7 \mathrm{~kg} \mathrm{ha}^{-1}$ ) mobilized (data not shown). Quantities were greatest from unamended $\left(\mathrm{N}_{\mathrm{m}}\right)$ and farmyard manure $\left(\mathrm{F}_{\mathrm{m}}\right)$ amended treatments. The C:N ratio of this eroded sediment was low indicating it was a potentially readily mineralizable soil fraction.

\section{Enrichment ratios}

Enrichment ratios were calculated for carbon and nitrogen using $\mathrm{C}$ and $\mathrm{N}$ concentrations from eroded soil and from surface soil of either $0-1.5 \mathrm{~cm}$ or $0-10 \mathrm{~cm}$ depth (Table 3 ). Average $C$ enrichment ratios ranged between $1.3-4.1$ for $0-$ $1.5 \mathrm{~cm}$ (Figure 3), and $1.7-4.3$ for $0-10 \mathrm{~cm}$. Average $\mathrm{N}$ enrichment ratios ranged between $3.0-6.3$ for $0-1.5 \mathrm{~cm}$ (Figure 4) and 2.6-5.9 for $0-10 \mathrm{~cm}$. There was little difference between enrichment ratios based on soil depth and variability between individual plots was high. At low sediment yields, there was a greater variation in enrichment ratio for both $\mathrm{C}$ and $\mathrm{N}$. These points correspond to treatments where runoff and consequently soil loss is least.
At higher sediment yields, the enrichment ratios show less variability, but enrichment ratios are still above 1.5 for carbon and 2 for nitrogen.

\section{DISCUSSION}

Runoff is a major component of the water balance in SAT environments and our results emphasise both this and the enormous potential of soil management to control its magnitude. Water diverted from runoff becomes available, after infiltration, for transpiration and drainage/percolation to the groundwater aquifer. A consequence of reducing runoff is therefore larger quantities of water available for crop production. A further consequence of reducing runoff is less soil and nutrient loss because soil erosion is reduced. In other words the plant available soil moisture storage is maintained and valuable plant nutrients are retained. We identified soil management practices, including tillage, organic amendments and rotations of perennial and annual crops, which control runoff and hence provide large and interacting benefits to crop production.

Our experiment showed that annual runoff from $20 \mathrm{~cm}$ deep tillage was consistently less from zero tillage, while $10 \mathrm{~cm}$ deep tillage was less in some years. However all of the benefit occurred immediately post tillage, before the soil had crusted (Yule et al. 1992; Rao et al. 1998a,b) and infiltration was similarly restricted for all tillage later in the cropping season, when short intraseason droughts may occur with resultant yield loss. Our results support the view that tillage is of limited temporal value in these soils (Yule et al. 1992) and that there are no persistent benefits of different tillage depths to crop yield (Vittal et al. 1983; Cogle et al. 1997). Soil erosion was not different for tillage treatments, and our results did not indicate that the loosening of soil via cultivation caused any greater soil erosion; the greatest effects were due to organic amendments, as discussed below.

Organic amendments (straw, farmyard manure), applied to the soil surface, caused large reductions in runoff and erosion and provided important crop yield benefits (Cogle $e t$ al. 1997). Their continued and cumulating benefit was due to factors such as protection of the soil surface from raindrop impact, the buildup of a soil biota population (Yule et al. 1992; Reddy et al. 1993; Cogle et al. 1994a,b) and to increases in organic carbon in surface soil. Long-term simulations also showed that the reduction in runoff translated into extra drainage below the root zone of between $81-138 \mathrm{~mm} \mathrm{yr}^{-1}$ (Cogle et al. 1996) meaning greater potential water availability from the groundwater aquifer. Reduced runoff following organic amendment, also meant reduced soil loss except on rare occasions when surface applied farmyard manure was transported in runoff during large storms. This loss of farmyard manure resulted in substantial nutrient losses, but the long-term benefit of farmyard manure application probably outweighs this loss.

Perennials and the residual effects of perennials generally produced less runoff and soil erosion than tillage by amendment factorial, except for sole pigeon pea early in the experiment. The reduced runoff from the perennials can be explained by cover and increased soil biota, while the residual effect of perennials in reducing runoff $(1992,1993)$ 
illustrated two responses. Firstly, it confirmed that straw cover reduced runoff regardless of the previous management. Secondly and perhaps more importantly, that one of the benefits of perennials to succeeding crops was an ability to stabilize the soil surface so that surface porosity was protected and decreases in infiltration due to raindrop impact and subsequent crusting were delayed. The higher $\mathrm{C}$ and $\mathrm{N}$ contents in perennial treatments suggest that the stability was related to larger organic matter inputs, however aggregate stability measurements were unable to quantify these changes (Bajracharya et al. 1996). Some of these benefits have been recognized as perennial pastures are already used as fodder resources, either in a cut and carry or for rotational grazing systems, and are recognized as valuable in watersheds for improving groundwater recharge (NK Sanghi, pers. comm.).

The best illustration of this second response is to compare PSt, PCSt and $\mathrm{T}_{0} \mathrm{~N}_{\mathrm{m}}$ during 1992 and 1993; there was little difference in runoff between PSt, which had a straw cover during the cropping phase, and PCSt, which had no straw cover, but both had substantially lower runoff than $\mathrm{T}_{0} \mathrm{~N}_{\mathrm{m}}$. It is likely that soil fauna, which were more active in these prior perennial treatments (Reddy et al. 1993), had improved soil surface condition and hence infiltration. In other words the surface protection provided by applied straw in PSt does not appear to have been necessary. That this trend was seen in two years supports this hypothesis. The unanswered question becomes 'how long will this benefit persist?' Under farm conditions it would also depend on other agronomic practices such as tillage, rotations and potential compaction by grazing animals.

During the experimental period, soil loss was less than $7 \mathrm{tha}^{-1}$, with rates dictated by runoff quantity. This meant that for the tillage by amendment factorial, losses were greatest for unamended treatments and least for straw covered $(100 \%$ cover $)$ treatments. There was a greater reduction for perennial and prior perennial treatments, which again suggests some change in surface soil properties and the larger organic carbon percentages found in organically amended and perennial rotations are good indicators of these changed soil properties. The project was conducted on a slope of $2 \%$, which is not unusual on these soils in the Indian SAT. Littleboy et al. (1996b) using simulation modelling, showed the damaging consequences, particularly when unamended, of cultivating steeper slopes.

Suspended load was a major part of eroded soil in the Alfisol. This fraction contains the smaller size fractions, including clay and also the lighter fractions such as organic matter. Both are important sources of plant nutrients. Some evidence is provided suggesting that at smaller runoff quantities a larger proportion of eroded soil is the fine fraction; this is understandable since higher runoff power would lead to greater movement of heavier soil particles and may help to explain the similarity in $\mathrm{N}$ and $\mathrm{C}$ losses from all tillage by amendment treatments i.e. the trend of reduced $\mathrm{N}$ and $\mathrm{C}$ loss for farmyard manure and straw amended soils is not as dramatic as that for runoff. The larger bandwidth for the $\mathrm{N}$ and $\mathrm{C}$ enrichment ratios at lower sediment yields also supports this conclusion.
A major immediate impact of soil erosion is its effect on nutrient losses. We have shown that loss of nitrogen up to $27 \mathrm{~kg} \mathrm{ha}^{-1}$ occurred in a system that was receiving split applications totalling to $100 \mathrm{~kg} \mathrm{Nha}^{-1}$. Our agronomic results showed that for the same treatments the crop removed between 69 and $100 \mathrm{~kg} \mathrm{~N} \mathrm{ha}^{-1}$. In other words up to $39 \%$ of potential crop $\mathrm{N}$ uptake was lost as a result of soil erosion. Hashim et al. (1998) has shown similar \% losses in other tropical countries and considered that net nutrient depletion via erosion and crop removal can lead to greater erosion, as plant cover and soil condition deteriorates. Nutrient loss, due to soil erosion, also contributes to the pollution of rivers and water bodies.

\section{CONCLUSION}

Runoff and soil loss were shown to vary greatly with soil management practices in the semiarid tropics. There were clear benefits of surface protection via organic amendments and the option of rotating well managed perennial species with crops was also successful. Since these practices also deliver yield benefits, fodder reserves and potential groundwater resources, farmers would clearly be advantaged by their implementation. One uncertainty for rotational systems however, is the persistence of the benefit of perennials following the commencement of annual cropping; and further long-term studies need to examine this, coupled with on farm trials with a livestock component. Nutrient loss during soil erosion was not directly related to runoff volume, due to higher $\mathrm{C}$ and $\mathrm{N}$ enrichment ratios at low runoff and sediment yields. Our findings emphasise the need to reduce runoff for nutrient conservation and for improved soil water availability and groundwater recharge in the semiarid tropics.

\section{ACKNOWLEDGEMENTS}

We thank the staff associated with the field project including M. Ali and G.P. Kumar, and N. Ramaswamy and P. Kistiah for maintaining and operating the experiment.

\section{REFERENCES}

Bajracharya RM Cogle AL Lal R Rao KPC Smith GD \& Yule DF 1996. Surface crusting as a constraint to sustainable management on a tropical Alfisol: I. Soil physical properties. Journal of Sustainable Agriculture 8, 25-44.

Cogle AL Rao KPC Reddy MV Srinivasan ST McGarry D Smith GD \& Yule DF 1994a. The impact of soil biota and cover on runoff and infiltration in a hardsetting Alfisol in the SAT. International Soil Conservation Conference. New Delhi pp 1546-1553.

Cogle AL Rao KPC Reddy MV Srinivasan ST McGarry D Smith GD \& Yule, DF 1994b. The role of biological practices and the soil biota in management of sealing, crusting and hardsetting soils. In Sealing, Crusting and Hardsetting Soils: Productivity and Conservation, eds HB So GD Smith SR Raine BM Schafer \& RJ Loch, Australian Society of Soil Science Inc, Brisbane pp. 305-324.

Cogle AL Littleboy M Rao KPC Smith GD \& Yule DF 1996. Soil management and production of Alfisols in the semiarid tropics. III Long term effects on the resource base and production. Australian Journal of Soil Research 34, 113-126.

Cogle AL Rao KPC Yule DF George PJ Srinivasan ST Smith GD \& Jangawad L 1997. Soil management options for Alfisols in the semiarid 
tropics : Annual and perennial crop production. Soil and Tillage Research 44, 235-253.

El-Swaify SA Pathak P Rego TJ \& Singh S 1985. Soil management for optimized productivity under rainfed conditions in the semi-arid tropics. Advances in Soil Science 1, 1-63.

GENSTAT 5 Committee, 1993. GENSTAT 5 Release 3 Reference Manual. Clarendon Press Oxford, pp. 796.

Hairsine PB Moran CJ \& Rose CW 1992. Recent developments regarding the influence of soil surface characteristics on overland flow and erosion. Australian Journal of Soil Research 30, 249-264.

Hashim GM Coughlan KJ \& Syers JK 1998. On site nutrient depletion: An effect and a cause of soil erosion. In Soil erosion at multiple scales: principles and methods for assessing causes and impacts, eds FWT Penning de Vries F Agus \& J Kerr CAB International. pp 207-221

Kampen J \& Burford JR 1980. Production systems, soil related constraints and potentials in the semi-arid tropics with special reference to India. In Priorities for alleviating soil related constraints to food production in the tropics. Los Banos Laguna. IRRI, pp. 141-165.

Littleboy M Cogle AL Rao KPC Smith GD \& Yule DF 1996a. Soil management and production of Alfisols in the semi-arid tropics. I Modelling the effects of surface cover and tillage on runoff and erosion. Australian Journal of Soil Research 34, 91-102.

Littleboy M Cogle AL Smith GD Rao KPC \& Yule DF 1996b. Soil management and production of Alfisols in the semi-arid tropics. IV Simulating decline in productivity caused by soil erosion. Australian Journal of Soil Research 34, 127-138.

Murthy RS \& Swindale LD 1993. Soil survey of ICRISAT farm and type area around Patancheru, Andhra Pradesh. National Bureau of Soil Survey and Land use Planning Publication 8, Nagpur 440010 India and International Crops Research Institute for the Semi arid tropics, Hyderabad, Andhra Pradesh 502324 India.

Pallis RG Okwach G Rose CW \& Saffigna PG 1990. Soil erosion processes and nutrient loss. I. The interpretation of enrichment ratio and nitrogen loss in runoff sediment. Australian Journal of Soil Research 28, 623-639.

Rao KPC Cogle AL Yule DF Smith GD \& Srinivasan ST 1992. Development of sustainable management systems for Alfisols: A biological approach. First Agricultural Science Congress, Indian Agricultural Research Institute, New Delhi pp 1287-1294.

Rao KPC Steenhuis TS Cogle AL Srinivasan ST Yule DF \& Smith GD 1998a. Rainfall infiltration and runoff from an Alfisol in semi-arid tropical India: I No till systems. Soil and Tillage Research 48, 51-60.

Rao KPC Steenhuis TS Cogle AL Srinivasan ST Yule DF \& Smith GD 1998b. Rainfall infiltration and runoff from an Alfisol in semi-arid tropical India: II Tilled systems. Soil and Tillage Research 48, 61-70.

Reddy MV Reddy VR Yule DF Cogle AL \& George PJ 1993. Decomposition of straw in relation to tillage, moisture and arthropod abundance in a semi-arid tropical Alfisol. Biology and Fertility of Soils, $17,45-50$.

Sehgal J \& Abrol IP 1992. Land degradation status: India. Desertification Bulletin No 21. UNEP.

Smith GD \& Thomas NP 1988. Monitoring small plot runoff with tipping buckets. Indian Journal of Dryland Agricultural Research and Development 3, 159-165.

Smith GD Jangawad LS \& Srivastava KL 1988. Castor roots in a Vertic Inceptisol. In Plant Roots and Their Environments, eds, BL McMichael \& H Persson, Proceedings of the International Root Research Society Root Environment Symposium, Uppsala Sweden August 1988. Elsevier, Amsterdam pp 533-542.

Smith GD Coughlan KJ Yule DF Laryea KB Srivastava KL Thomas NP \& Cogle AL 1992. Soil management options to reduce runoff and erosion on a hardsetting Alfisol in the semi-arid tropics. Soil and Tillage Research 25, 195-215.

Vittal KPR Vijayalakshmi K \& Rao UMB 1983. Effect of deep tillage on dryland crop production in red soils of India. Soil and Tillage Research 3, 377-384.

Yule DF Cogle AL Smith GD Rao KPC \& George PJ 1992. Soil management of Alfisols for water conservation and utilization. Journal of Indian Water Resources Society 11, 10-13.

Received October 2000, accepted after revision July 2001. 